\title{
Review: environmental friendly lead-free piezoelectric materials
}

\author{
P. K. Panda
}

Received: 20 April 2009/Accepted: 25 May 2009/Published online: 7 July 2009

(C) The Author(s) 2009. This article is published with open access at Springerlink.com

\begin{abstract}
Lead zirconate titanate (PZT) based piezoelectric materials are well known for their excellent piezoelectric properties. However, considering the toxicity of lead and its compounds, there is a general awareness for the development of environmental friendly lead-free materials as evidenced from the legislation passed by the European Union in this effect. Several classes of materials are now being considered as potentially attractive alternatives to PZTs for specific applications. In this paper, attempts have been made to review the recent developments on lead-free piezo materials emphasizing on their preparation, structure-property correlation, etc. In this context, perovskite systems such as bismuth sodium titanate, alkali niobates $\left(\mathrm{ANbO}_{3}\right)$, etc. and non-perovskites such as bismuth layer-structured ferroelectrics are reviewed in detail. From the above study, it is concluded that some lead-free compositions show stable piezoelectric responses even though they do not match the overall performance of PZT. This has been the stimulant for growing research on this subject. This topic is of current interest to the researchers worldwide as evidenced from the large number of research publications. This has motivated us to come out with a review article with a view that it would give further impetus to the researchers already working in this area and also draw the attention of the others.
\end{abstract}

P. K. Panda $(\bowtie)$

Materials Science Division, National Aerospace Laboratories, P.O. Box 1779, Kodihalli, Bangalore 560017, India

e-mail:pkpanda@nal.res.in

\section{Introduction}

Piezoelectricity (pressure electricity) was discovered by Nobel laureates Pierre and Jacques Curie in 1880 [1] during their study of the effects of pressure on the generation of electrical charge by crystals such as quartz, tourmaline, and Rochelle salt. In fact, the development of an electrical charge under the application of mechanical pressure or vice versa is referred to as the piezoelectric effect. Low piezoelectricity is the main drawback of the natural piezoelectric materials. A major break through came with the discovery of PZT and $\mathrm{BaTiO}_{3}$ in the 1950s [2,3] and the family of these materials exhibited very high dielectric and piezoelectric properties. To date, PZT is one of the most widely exploited and extensively used piezoelectric materials, having secured a permanent place in the field of material science and engineering. They are widely used as sensor and actuator devices [4-7], multilayered capacitors, as hydrophones, etc. with an estimated market of tens of billions of dollars worldwide. However, lead oxide, which is a component of PZT, is highly toxic and its toxicity is further enhanced due to its volatilization at high temperature particularly during calcination and sintering causing environmental pollution [8].

According to the recent developments, European Union (EU) is planning to restrict the use of hazardous substances such as lead as well as other heavy metals [9, 10]. However, there is no equivalent substitute for PZT; therefore, its use is still continued. This may be a temporary respite, but the legislation certainly impressed the researchers to develop alternative lead-free piezoelectric materials in order to replace lead-based materials [11, 12]. There had been many attempts by researchers in the past to develop alternative lead-free materials but the properties are nowhere near to the PZT system. Basically, the lead-free 
systems are (i) perovskites, i.e., $\mathrm{BNT}, \mathrm{BaTiO}_{3}(\mathrm{BT}), \mathrm{KNbO}_{3}$, $\mathrm{NaTaO}_{3}$, etc., (ii) non-perovskites, i.e., bismuth layerstructured ferroelectrics (BLSF), tungsten-bronze type ferroelectrics, etc. While the perovskites are suitable for actuator and high power application, BLSF seems to be a candidate for ceramic filter and resonator applications. Apart from polycrystalline lead-free materials, lead-free piezoelectric single crystals, e.g., langasite and ferroelectric ceramics with tungsten-bronze structure have been reported [10]. The perovskite type ferroelectrics are hopeful candidates for lead-free piezoelectric ceramics because its anisotropy in piezoelectric properties are large compared to other ferroelectrics. A list of lead-free piezo materials and their properties is presented in Table 1.

The large piezoelectric response of PZT results from two factors. Primarily, the stereo-chemical activity of the $6 s^{2}$ lone pair on the lead ion causes large structural distortions from the cubic perovskite phase that results in strong coupling between the electronic and structural degrees of freedom [13]. Bi-based compounds have similar or larger levels of ion off centering than $\mathrm{Pb}$-based compounds, driven by the stereo chemically active $6 s^{2}$ lone pairs on the $\mathrm{Bi}^{3+}$ ion. This leads to large ferroelectric polarizations. In most common ferroelectrics, ion off centering is mainly contributed by the B-site cations to the ferroelectricity so as to increase the chemical bonding between their valence $d$ orbital and the surrounding oxygen $2 p$ orbital (second-order Jahn Teller, SOJT) effect [14]. Bismuth is non-toxic in its oxide forms; indeed, the active ingredient of a popular antacid is bismuth salicylate. Some of the toxic effects of lead and its hazardous consequences on health are discussed in the next section.

\section{Toxic effects of lead}

The important symptoms of lead poisoning are fatigue, aches in muscles and joints, abdominal discomfort, etc. Some of the symptoms and signs of lead poisoning are shown in Table 2. Patients with poor dental hygiene may exhibit a blue line at the dental margin of the gums due to deposition of lead sulfide. Lead poisoning has long been considered as an environmental health hazard, for its adverse effects on intellectual and neurological development [15-17]. The main route of absorption in adults is the respiratory tract where 30-70\% of inhaled lead (mostly the inorganic form like oxides and salts) goes into the circulatory system. For a reasonably well-controlled occupational exposure, blood lead value ranges between 1.45 and $2.4 \mathrm{~mol} \mathrm{~L}^{-1}\left(30-50 \mu \mathrm{g} 100 \mathrm{~mL}^{-1}\right)$ with a provision that there is six monthly monitoring $[18,19]$.

Lead has three important biochemical properties that contribute to its toxic effects on humans. First, lead being an electropositive metal has high affinity for enzymes,

Table 2 Symptoms and signs of lead poisoning [15]

\begin{tabular}{lll}
\hline Mild & Moderate & Severe \\
\hline Lethargy & Anemia & Convulsions \\
Anorexia & Headache & Coma \\
$\begin{array}{c}\text { Abdominal } \\
\text { discomfort }\end{array}$ & Abdominal cramps & Encephalopathy \\
Arthralgia & $\begin{array}{l}\text { Gingival lead line } \\
\text { Peripheral neuropathy } \\
\text { (motor) }\end{array}$ & Renal failure \\
& & \\
\hline
\end{tabular}

Table 1 Properties of some selected lead-free compositions

\begin{tabular}{|c|c|c|c|c|c|}
\hline Systems & Compositions & $T_{\mathrm{c}}\left({ }^{\circ} \mathrm{C}\right)$ & $d_{33}(\mathrm{pC} / \mathrm{N})$ & $K$ & References \\
\hline $\mathrm{BaTiO}_{3}$ & BT & 130 & 140 & 1400 & [121] \\
\hline BNT & $\left(\mathrm{Bi}_{0.5} \mathrm{Na}_{0.5}\right) \mathrm{TiO}_{3}$ & 310 & 64 & 302.6 & {$[60]$} \\
\hline BNT-BT & $\left(\mathrm{Na}_{0.5} \mathrm{Bi}_{0.5}\right)_{0.92} \mathrm{Ba}_{0.08} \mathrm{TiO}_{3}$ & 280 & 125 & 625 & {$[28]$} \\
\hline $\mathrm{BNT}-\mathrm{BT}-\mathrm{Nb}_{2} \mathrm{O}_{5}$ & $\left(\mathrm{Na}_{0.5} \mathrm{Bi}_{0.5}\right)_{0.92} \mathrm{Ba}_{0.08} \mathrm{TiO}_{3}+x \mathrm{Nb}_{2} \mathrm{O}_{5}$ & 250 & 149 & 1230 & [47] \\
\hline BNT-BT- $\mathrm{CeO}_{2}+\mathrm{La}_{2} \mathrm{O}_{3}$ & $\left(\mathrm{Na}_{0.5} \mathrm{Bi}_{0.5}\right) 0.94-6 \mathrm{BaTiO}_{3}+0.5 \mathrm{~mol} \% \mathrm{CeO}_{2}+0.5 \mathrm{~mol} \% \mathrm{La}_{2} \mathrm{O}_{3}$ & - & 162 & 831 & {$[28]$} \\
\hline $\mathrm{BNT}-\mathrm{BT}-\mathrm{MnCO}_{3}$ & $\left(\mathrm{Na}_{0.5} \mathrm{Bi}_{0.5}\right)_{0.92}-\mathrm{Ba}_{0.08} \mathrm{TiO}_{3}+x \mathrm{~mol} \% \mathrm{MnCO}_{3}$ & 243 & 160 & - & {$[52]$} \\
\hline $\mathrm{BKT}-\mathrm{BT}-\mathrm{MnCO}_{3}$ & & 174 & 117 & 2300 & {$[10]$} \\
\hline $\mathrm{BNT}-\mathrm{BK}-\mathrm{BT}$ & $\begin{array}{l}\left(\mathrm{Bi}_{0.5} \mathrm{Na}_{0.5}\right) \mathrm{TiO}_{3}-\left(\mathrm{Bi}_{0.5} \mathrm{~K}_{0.5}\right) \mathrm{TiO}_{3}-\mathrm{BaTiO}_{3} \\
(1-3 x) \mathrm{BNT}-2 x \mathrm{BKT}-\mathrm{BT}\end{array}$ & 125 & 150 & - & {$[65]$} \\
\hline BNT-BZT & $\left(\mathrm{Bi}_{0.5} \mathrm{Na}_{0.5}\right) \mathrm{TiO}_{3}-\mathrm{Ba}(\mathrm{Ti}, \mathrm{Zr}) \mathrm{O}_{3}$ & 244 & 147 & 8814 & {$[60]$} \\
\hline BNT-BKT-SrTiO 3 & $\mathrm{Bi}_{0.5}\left(\mathrm{Na}_{0.84} \mathrm{~K}_{0.16}\right)_{0.5} \mathrm{TiO}_{3}+x \mathrm{SrTiO}_{3}$ & 292 & 185 & 868 & {$[57]$} \\
\hline BNKLi-BT & $\begin{array}{l}\left.\mathrm{Bi}_{1-z}\left(\mathrm{Na}_{1-x-y-z} \mathrm{~K}_{x} \mathrm{Li}_{y}\right)\right]_{0.5} \mathrm{Ba}_{z} \mathrm{TiO}_{3} \\
\left({ }_{\mathrm{BN}-x / y / z}\right) \mathrm{BN}-0.15 / 0.075 / 0.02\end{array}$ & 210 & 205 & 1040 & {$[27]$} \\
\hline$(\mathrm{K}, \mathrm{Na}) \mathrm{NbO}_{3}$ & $\begin{array}{l}\left(\mathrm{K}_{0.5} \mathrm{Na}_{0.5}\right)_{1-2 y} \mathrm{AE}_{y} \mathrm{NbO}_{3} \\
\mathrm{AE}=\mathrm{Mg}, \mathrm{Ca}, \mathrm{Sr}, \mathrm{Ba}\end{array}$ & 400 & 95 & 500 & [109] \\
\hline
\end{tabular}


which are essential for the synthesis of hemoglobin. Second, divalent lead acts in a manner similar to calcium inhibiting mitochondrial oxidative phosphorylation thus reducing the intelligence quotient. Lead can also affect the genetic transcription of DNA by interaction with nucleic acid binding proteins [20]. The most important initial aspect of management of lead poisoning is the removal of the patient from the source of exposure [21] and second by using chelating agents (EDTA) that form complexes with lead and hence are excreted out [22-25].

In this paper, overview of current developments in various lead-free piezoelectric ceramics, effects of various dopants to enhance the piezo properties were presented.

\section{Perovskite-structured lead-free ferroelectrics}

The perovskite-type $\left(\mathrm{ABO}_{3}\right)$ ferroelectrics such as $\mathrm{BaTiO}_{3}$ (BT), $\left(\mathrm{Bi}_{0.5} \mathrm{Na}_{0.5}\right) \mathrm{TiO}_{3}$ (BNT), $\mathrm{KNbO}_{3}, \mathrm{NaTaO}_{3}$, etc. are well-known lead-free piezoelectric materials. These ceramics show relatively large piezoelectric constant. However, the main drawbacks generally are low Curie temperatures $\left(T_{\mathrm{c}}\right)$, difficulties in poling treatments and/or low relative densities [10].

\section{$\mathrm{BaTiO}_{3}$ system}

Barium titanate, $\mathrm{BaTiO}_{3}(\mathrm{BT})$ is one of the perovskites discovered very early. It has a relatively high electromechanical coupling factor $\left(k_{33}\right)$ and has been partially used for piezoelectric applications such as sonar although its main use is for capacitor applications. It has the advantage of easy manufacture by various ceramic techniques. BT has a low Curie temperature $\left(T_{\mathrm{c}}=120^{\circ} \mathrm{C}\right)$ causing the working temperature range of this ceramic narrow for actual piezoelectric applications. To increase the $T_{\mathrm{c}}$ of $\mathrm{BaTiO}_{3}$-based ceramics, a binary system of $\mathrm{BaTiO}_{3}-$ $\left(\mathrm{Bi}_{0.5} \mathrm{~K}_{0.5}\right) \mathrm{TiO}_{3}$ (BKT) was investigated. The $T_{\mathrm{c}}$ of $\mathrm{BKT}$ was reported to be about $380{ }^{\circ} \mathrm{C}$ [10].

$\mathrm{BaTiO}_{3}$ and $\left(\mathrm{Bi}_{0.5} \mathrm{~K}_{0.5}\right) \mathrm{TiO}_{3}$ system

$\mathrm{BaTiO}_{3}$ and $\left(\mathrm{Bi}_{0.5} \mathrm{~K}_{0.5}\right) \mathrm{TiO}_{3}$ are well known lead-free piezoelectric materials with the tetragonal symmetry. Two solid solution systems, i.e., $(1-x)\left(\mathrm{Bi}_{0.5} \mathrm{Na}_{0.5}\right) \mathrm{TiO}_{3}-x \mathrm{BaTiO}_{3}$ (BNBT-100x) and $(1-y)\left(\mathrm{Bi}_{0.5} \mathrm{Na}_{0.5}\right) \mathrm{TiO}_{3}-y\left(\mathrm{Bi}_{0.5} \mathrm{~K}_{0.5}\right) \mathrm{TiO}_{3}$
(BNKT-100y) had been already reported by Takenaka et al. [26] and Sasaki et al. [27], respectively. It was reported that MPB compositions existed on $x=0.06-0.07$ for BNBT-100x and $\mathrm{y}=0.16-0.20$ for BNKT-100y, respectively. BNBT system is considered to be a strong candidate for lead-free piezoelectric ceramic material because the solid solution shows good piezoelectric properties. It has also been reported that further enhancement in the piezoelectric properties of $\left(\mathrm{Bi}_{05} \mathrm{Na}_{05}\right)_{094} \mathrm{Ba}_{006} \mathrm{TiO}_{3}$ (abbreviated as BNBT-6) ceramics can be enhanced by adding $\mathrm{Nb}_{2} \mathrm{O}_{5}$ and $\mathrm{CeO}_{2}$ [28]. Perovskite type ceramics seems to be suitable for actuator and high power applications because of high $T_{\mathrm{c}}$. For $\mathrm{BaTiO}_{3}$-based solid solutions, that is $(1-x) \mathrm{BT}-x \mathrm{BKT}$, the $T_{\mathrm{c}}$ increases with increasing amount of $x$. Table 3 summarizes the Curie temperature $\left(T_{\mathrm{c}}\right)$ and piezoelectric properties of BTBK ceramics [10].

\section{$\left(\mathrm{Bi}_{1 / 2} \mathrm{Na}_{1 / 2}\right) \mathrm{TiO}_{3}$ system}

$\left(\mathrm{Bi}_{1 / 2} \mathrm{Na}_{1 / 2}\right) \mathrm{TiO}_{3}$ (BNT) is one of the important lead-free piezoelectric materials with perovskite structure discovered by Smolenskii et al. [29]. As $\left(\mathrm{Bi}_{1 / 2} \mathrm{Na}_{1 / 2}\right) \mathrm{TiO}_{3}$ composition exhibits strong ferroelectric properties of a large remnant polarization, $P_{\mathrm{r}}=38 \mu \mathrm{C} / \mathrm{cm}^{2}$ and high Curie temperature, $T_{\mathrm{c}}=320^{\circ} \mathrm{C}$, it has been considered for lead-free piezoelectric ceramics as an alternative to the widely used leadbased piezoelectric materials [30]. The main drawback of this material is its high conductivity, consequently giving problems in the poling process. In addition, BNT ceramics need high sintering temperature $\left(>1200{ }^{\circ} \mathrm{C}\right)$ to obtain the dense body. Thus BNT is considered to be a promising candidate for lead-free piezoelectric ceramics with balanced ferroelectric properties.

\section{Effect of dopants on BNT ceramics}

For the pure BNT system, $d_{33}$ lies in the range of 57$64 \mathrm{pC} / \mathrm{N}$ as discovered by researchers pointed out in Table 4. The large piezoelectricity is expected on the BNTbased solid solutions with a morphotropic phase boundary (MPB). It has been reported that BNT-based compositions modified with $\mathrm{BaTiO}_{3}, \mathrm{BiKTiO}_{3}, \mathrm{NaNbO}_{3}, \mathrm{BiFeO}_{3}, \mathrm{MnO}_{2}$, $\mathrm{Sc}_{2} \mathrm{O}_{3}, \mathrm{La}_{2} \mathrm{O}_{3}, \mathrm{CeO}_{2}$, etc. [31-44] showed improved properties and easier treatment in poling process when compared with pure BNT ceramics.

Table 3 Properties of BKT-BT- $\mathrm{MnCO}_{3}$ system

\begin{tabular}{lcccc}
\hline Composition & $d_{33}(\mathrm{pC} / \mathrm{N})$ & $K$ & $T_{\mathrm{c}}\left({ }^{\circ} \mathrm{C}\right)$ & References \\
\hline$(1-x) \mathrm{BaTiO}_{3}-x\left(\mathrm{Bi}_{0.5} \mathrm{~K}_{0.5}\right) \mathrm{TiO}_{3}+\mathrm{MnCO}_{3}(\mathrm{BTBK}-20+\mathrm{Mn})$ & 58.9 & 467 & 223 & {$[10]$} \\
$(1-x) \mathrm{BaTiO}_{3}-x\left(\mathrm{Bi}_{0.5} \mathrm{~K}_{0.5}\right) \mathrm{TiO}_{3}+\mathrm{MnCO}_{3}(\mathrm{BTBK}-5+\mathrm{Mn})$ & 117 & 2300 & 174 & {$[10]$} \\
\hline
\end{tabular}


Table 4 Properties of BNT system

\begin{tabular}{lllllll}
\hline Composition & Density $(\mathrm{g} / \mathrm{cc})$ & $d_{33}(\mathrm{pC} / \mathrm{N})$ & Tan $\delta(\%)$ & $K$ & $T_{\mathrm{c}}\left({ }^{\circ} \mathrm{C}\right)$ & References \\
\hline$\left(\mathrm{Bi}_{0.5} \mathrm{Na}_{0.5}\right) \mathrm{TiO}_{3}$ & 5.32 & 64 & 57 & 1.752 & 302.6 & 310 \\
$\left(\mathrm{Bi}_{0.5} \mathrm{Na}_{0.5}\right) \mathrm{TiO}_{3}$ & - & 61 & 0.011 & 240 & 450 & {$[60]$} \\
$\left(\mathrm{Bi}_{0.5} \mathrm{Na}_{0.5}\right) \mathrm{TiO}_{3}$ & - & 4.11 & 467 & - & {$[42]$} \\
\hline
\end{tabular}

Effect of $\mathrm{La}_{2} \mathrm{O}_{3}$ In order to improve the piezo properties, Herabut and Safari [45] studied the effect of La dopant as additive and concluded that the $d_{33}$ value increases from 64 to $92 \mathrm{pC} / \mathrm{N}$ for BNT doped with 6 mole\% lanthanum oxide (Table 5). The piezoelectric properties were diminished once the doping level is beyond 2 at.\% La. This is due to a phase distortion from rhombohedral to pseudo cubic phase. Furthermore, the dielectric constant and dissipation factor at the Curie point decrease when the amount of La doping in BNT increases.

Effect of $\mathrm{NaNbO}_{3}$ Li et al. prepared lead-free bismuth sodium titanate-sodium niobate (BNT-NN), $\left[\mathrm{Na}_{0.5(1+x)}\right.$ $\left.\mathrm{Bi}_{0.5(1-x)}\right]\left(\mathrm{Ti}_{(1-x)}-\mathrm{Nb}_{x}\right) \mathrm{O}_{3}$ ceramics using conventional

Table 5 Effect of dopants on BNT system

\begin{tabular}{|c|c|c|c|c|c|}
\hline Composition & $\begin{array}{l}d_{33} \\
(\mathrm{pC} / \mathrm{N})\end{array}$ & $\begin{array}{l}\operatorname{Tan} \delta \\
(\%)\end{array}$ & $K$ & $\begin{array}{l}T_{\mathrm{c}} \\
\left({ }^{\circ} \mathrm{C}\right)\end{array}$ & References \\
\hline $\begin{array}{c}\left(\mathrm{Bi}_{0.5} \mathrm{Na}_{0.5}\right)_{(1-1.5 x)} \mathrm{La}_{x} \mathrm{TiO}_{3} \\
x=(0-0.6 \mathrm{~mol} \%)\end{array}$ & 92 & 0.04 & 560 & & [42] \\
\hline$x=1$ & 80 & 0.015 & 375 & 370 & \\
\hline$x=1.72$ & 91 & 0.04 & 550 & 345 & \\
\hline$x=2$ & 89 & 0.033 & 495 & 335 & \\
\hline$x=3$ & - & 0.036 & 770 & 365 & \\
\hline $\begin{array}{l}\left(\mathrm{Bi}_{0.5} \mathrm{Na}_{0.5}\right) \mathrm{TiO}_{3}- \\
\mathrm{NaNbO}_{3}\end{array}$ & & & & & [30] \\
\hline$x=0.01$ & 80 & 5.60 & 637 & - & \\
\hline$x=0.02$ & 88 & 5.90 & 624 & - & \\
\hline$x=0.03$ & 60 & 5.96 & 754 & - & \\
\hline$x=0.04$ & 50 & 6.26 & 753 & - & \\
\hline$x=0.05$ & 32 & 5.40 & 801 & _- & \\
\hline
\end{tabular}

ceramic technique [46]. They concluded that $d_{33}$ increases from 64 to $88 \mathrm{pC} / \mathrm{N}$ for $2 \mathrm{~mol} \%$ of $\mathrm{NaNbO}_{3}$ and then decreases gradually. However, the dielectric constant increases gradually with increase in $\mathrm{NaNbO}_{3}$ content. This is attributed to the co-effect of the soft additive $\mathrm{Nb}^{5+}$ ion doping at B-site and hard additive $\mathrm{Na}^{+}$ion doping at A-site. However, with further increasing the doping content of $\mathrm{NaNbO}_{3}(x=0.03-0.05)$, the piezoelectric properties decreased, which may be the reason for the dominant doping of $\mathrm{Na}^{+}$ion shown in Table 5 [30].

Effect of $\mathrm{BaTiO}_{3} \quad \mathrm{BNT}-\mathrm{BaTiO}_{3}$ (BNBT) showed the existence of a rhombohedral-tetragonal MPB. Takenaka reported that BNT-based solid solutions with a rhombohedral-tetragonal MPB compositions showed higher piezoelectric and pyroelectric properties when compared with unmodified BNT ceramics [47]. It has been reported by Wang et al. [48] and Li et al. [49] that the composition near the MPB has relatively large piezoelectric properties (Table 6). They reached at the conclusion that addition of $\mathrm{BaTiO}_{3}(6 \mathrm{~mol} \%$ or 0.06$)$ increases the $d_{33}$ value $\left(d_{33}=129 \mathrm{pC} / \mathrm{N}\right)$ compared to pure BNT $\left(d_{33}=64 \mathrm{pC} / \mathrm{N}\right)$ [50-52].

Effect of $\mathrm{Bi}_{2} \mathrm{O}_{3} \cdot \mathrm{Sc}_{2} \mathrm{O}_{3}$ Dielectric, piezoelectric, and ferroelectric properties of the BNT-based solid solution $(1-x)$ $\left(\mathrm{Bi}_{0.5} \mathrm{Na}_{0.5}\right) \quad \mathrm{TiO}_{3}-x\left(\mathrm{Bi}_{2} \mathrm{O}_{3} \cdot \mathrm{Sc}_{2} \mathrm{O}_{3}\right)_{0.5}$ was also investigated from the view point of a new group of lead-free piezoelectric ceramics (Table 7) [53]. The effects of modified $\mathrm{Bi}^{3+}$ ions on the dielectric, piezoelectric, and ferroelectric properties for a pseudo-three-component system $a\left(\mathrm{Bi}_{1 / 2} \mathrm{Na}_{1 / 2}\right) \mathrm{TiO}_{3}-b \mathrm{KNbO}_{3}-c\left(\mathrm{Bi}_{2} \mathrm{O}_{3} \cdot \mathrm{Sc}_{2} \mathrm{O}_{3}\right)_{0.5}$ were

Table 6 Properties of BNT-BT system

\begin{tabular}{|c|c|c|c|c|c|}
\hline Composition & $d_{33}(\mathrm{pC} / \mathrm{N})$ & $\operatorname{Tan} \delta(\%)$ & $K$ & $T_{\mathrm{c}}\left({ }^{\circ} \mathrm{C}\right)$ & References \\
\hline$\left(\mathrm{Na}_{0.5} \mathrm{Bi}_{0.5}\right)_{0.94} \mathrm{Ba}_{0.06} \mathrm{TiO}_{3}$ & 125 & 1.3 & 625 & 288 & {$[26]$} \\
\hline$\left(\mathrm{Na}_{0.5} \mathrm{Bi}_{0.5}\right)_{0.92} \mathrm{Ba}_{0.08} \mathrm{TiO}_{3}$ & 125 & - & - & 280 & {$[52]$} \\
\hline$(1-x)\left(\mathrm{Na}_{0.5} \mathrm{Bi}_{0.5}\right) \mathrm{TiO}_{3}-x \mathrm{BaTiO}_{3}$ & & & & & {$[47]$} \\
\hline$x=0.02$ & 78 & 1.73 & 402 & - & \\
\hline$x=0.04$ & 87 & 2.07 & 445 & - & \\
\hline$x=0.06$ & 122 & 1.79 & 601 & - & \\
\hline$x=0.08$ & 112 & 2.04 & 841 & - & \\
\hline$x=0.1$ & 94 & 2.39 & 764 & - & \\
\hline$\left(\mathrm{Na}_{0.5} \mathrm{Bi}_{0.5}\right) \mathrm{TiO}_{3}-6 \mathrm{BaTiO}_{3}$ & 117 & 2.5 & 776 & - & [49] \\
\hline
\end{tabular}


Table 7 Properties of $(1-x)\left(\mathrm{Bi}_{0.5} \mathrm{Na}_{0.5}\right) \mathrm{TiO}_{3}-x\left(\mathrm{Bi}_{2} \mathrm{O}_{3} \cdot \mathrm{Sc}_{2} \mathrm{O}_{3}\right)_{0.5}$ system

\begin{tabular}{llllll}
\hline Composition & $d_{33}(\mathrm{pC} / \mathrm{N})$ & Tan $\delta(\%)$ & $K$ & $T_{\mathrm{c}}\left({ }^{\circ} \mathrm{C}\right)$ & References \\
\hline$\left(\mathrm{Bi}_{0.51} \mathrm{Na}_{0.49}\right) \mathrm{Sc}_{0.02} \mathrm{Ti}_{0.98} \mathrm{O}_{3}$ & 74.7 & 5.11 & 431 & 358 & {$[50]$} \\
\hline
\end{tabular}

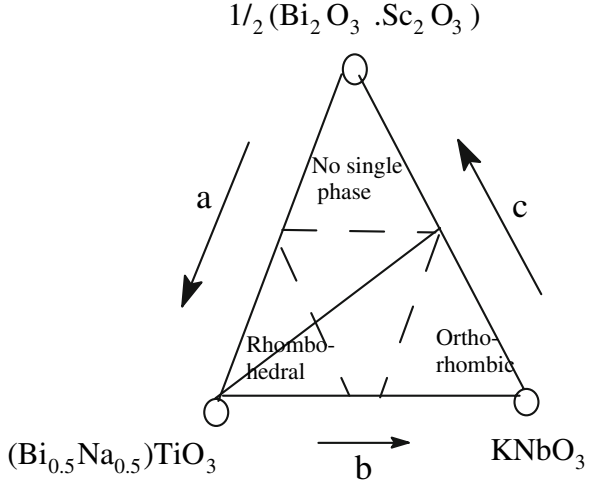

Fig. 1 Phase relation between $\left(\mathrm{Bi}_{0.5} \mathrm{Na}_{0.5}\right) \mathrm{TiO}_{3}, \quad \mathrm{KNbO}_{3}$, and $\left(\mathrm{Bi}_{2} \mathrm{O}_{3} \cdot \mathrm{Sc}_{2} \mathrm{O}_{3}\right)_{0.5}[32]$

studied and they concluded that the $\mathrm{Bi}^{3+}$ ion has an effect on the coercive field, $E_{\mathrm{c}}$ [54]. $E_{\mathrm{c}}$ becomes higher when the amount of modified $\mathrm{Bi}$ ions is increased thus making poling difficult. On the other hand, coercive field is decreased when the amount of modified $\mathrm{Bi}$ ions is decreased; making poling easier and $k_{33}$ is relatively higher. Hence they can be used as superior lead-free or low lead content piezoelectric materials because the poling process stands a better chance of success compared with non-modified BNT ceramics. Figure 1 shows the phase relation between $\left(\mathrm{Bi}_{1 / 2} \mathrm{Na}_{1 / 2}\right)$ $\mathrm{TiO}_{3}, \mathrm{KNbO}_{3}$, and $\left(\mathrm{Bi}_{2} \mathrm{O}_{3} \cdot \mathrm{Sc}_{2} \mathrm{O}_{3}\right)_{0.5}$ on pseudo-threecomponent system.

Effect of $\mathrm{La}, \mathrm{Nb}, \mathrm{Co}$ Influence of non-stoichiometry and doping on piezoelectric properties and structure of
BNT-BT based solid solutions near the MPB were studied by $\mathrm{Chu}$ et al. [50]. Their preliminary research has indicated that cerium oxide is an effective additive for BNBT ceramics for the development of the BNT lead-free system [14]. From Table 8, they concluded that similar to PZTbased ceramics, $\mathrm{Nb}^{5+}$ can be seen as soft additive which leads to the enhancement of piezoelectric constant, dielectric constant, dielectric loss, etc. The B-site doping of $\mathrm{Co}^{3+}$ (hard additive) in this system enhanced the compositional inhomogeneity, which results in the multiphase character over a relatively wide temperature range. Piezoelectric coefficient, $d_{33}$ of BNBT6-La and BNBT6-La-Nb, in which $\mathrm{La}^{3+}$ is added, is enhanced. These phenomena are like soft doping in the case with PZT-based ceramics. Since $\mathrm{La}^{3+}$ has an ionic radius of $1.06 \AA$, it will substitute $\mathrm{Bi}^{3+}$ of A-site because of the same valence. This substitution will result in an aberrance of crystal structure that benefits the reorientation of domains during the polarization process increasing $d_{33}$. For BNBT6-Co, $d_{33}$ goes up to $139 \mathrm{pC} / \mathrm{N}$, which can be explained with the remarkable growth of grain size after $\mathrm{Co}^{3+}$ doping and the value decreases after La addition.

Effect of $\mathrm{La}_{2} \mathrm{O}_{3}$ and $\mathrm{CeO}_{2}$ Some further enhancement in these properties was reported by adding $\mathrm{La}_{2} \mathrm{O}_{3}$ and $\mathrm{CeO}_{2}$. From Table 8, it could be concluded that addition of equal amount of $0.5 \mathrm{~mol} \% \mathrm{CeO}_{2}$ together with $0.5 \mathrm{~mol} \%$ of $\mathrm{La}_{2} \mathrm{O}_{3}$ increases $d_{33}$ value from 129 to $162 \mathrm{pC} / \mathrm{N}$. The dielectric constant also increases from 625 to 831. It has been reported that $\mathrm{CeO}_{2}$ has the dual effect of improving the piezoelectric properties of BNBT-6 ceramics and

Table 8 Effect of dopants on BNT-BT system

\begin{tabular}{|c|c|c|c|c|c|c|}
\hline Composition & Density (g/cc) & $d_{33}(\mathrm{pC} / \mathrm{N})$ & $\operatorname{Tan} \delta(\%)$ & $K$ & $T_{\mathrm{c}}\left({ }^{\circ} \mathrm{C}\right)$ & References \\
\hline$\left(\mathrm{Na}_{0.5} \mathrm{Bi}_{0.5}\right)_{0.92} \mathrm{Ba}_{0.08} \mathrm{TiO}_{3}+x \mathrm{Nb}_{2} \mathrm{O}_{5}(\mathrm{NBBT} 83)$ & - & 149 & 3.90 & 1230 & 250 & [47] \\
\hline$\left(\mathrm{Na}_{0.5} \mathrm{Bi}_{0.5}\right)_{0.92}-x \mathrm{Ba}_{0.08} \mathrm{TiO}_{3}+x \mathrm{Co}_{2} \mathrm{O}_{3}(\mathrm{NBBT} 84)$ & - & 108 & 1.50 & 450 & 245 & \\
\hline$\left(\mathrm{Na}_{0.5} \mathrm{Bi}_{0.5}\right) \mathrm{TiO}_{3}-6 \mathrm{BaTiO}_{3}+\mathrm{La}(\mathrm{BNBT} 6)+\mathrm{La}$ & - & 125 & 4.5 & 1576 & - & [49] \\
\hline$\left(\mathrm{Na}_{0.5} \mathrm{Bi}_{0.5}\right) \mathrm{TiO}_{3}-6 \mathrm{BaTiO}_{3}+\mathrm{Nb}(\mathrm{BNBT} 6)+\mathrm{Nb}$ & - & 118 & 4.6 & 1614 & - & \\
\hline$\left(\mathrm{Na}_{0.5} \mathrm{Bi}_{0.5}\right) \mathrm{TiO}_{3}-6 \mathrm{BaTiO}_{3}+\mathrm{La}-\mathrm{Co}(\mathrm{BNBT} 6)+\mathrm{La}-\mathrm{Co}$ & - & 127 & 2.1 & 1284 & - & \\
\hline$\left(\mathrm{Na}_{0.5} \mathrm{Bi}_{0.5}\right) \mathrm{TiO}_{3}-6 \mathrm{BaTiO}_{3}+\mathrm{La}-\mathrm{Nb}(\mathrm{BNBT} 6)+\mathrm{La}-\mathrm{Nb}$ & - & 135 & 2.3 & 1664 & - & \\
\hline$\left(\mathrm{Na}_{0.5} \mathrm{Bi}_{0.5}\right) \mathrm{TiO}_{3}-6 \mathrm{BaTiO}_{3}+\mathrm{Co}(\mathrm{BNBT} 6)+\mathrm{Co}$ & - & 139 & 2.3 & 1200 & - & \\
\hline$\left(\mathrm{Na}_{0.5} \mathrm{Bi}_{0.5}\right) 0.94-6 \mathrm{BaTiO}_{3}+0.5 \mathrm{~mol} \% \mathrm{CeO}_{2}+0.25 \mathrm{~mol} \% \mathrm{La}_{2} \mathrm{O}_{3}$ & 5.67 & 158 & 1.7 & 787 & - & {$[28]$} \\
\hline$\left(\mathrm{Na}_{0.5} \mathrm{Bi}_{0.5}\right) 0.94-6 \mathrm{BaTiO}_{3}+0.5 \mathrm{~mol} \% \mathrm{CeO}_{2}+0.5 \mathrm{~mol} \% \mathrm{La}_{2} \mathrm{O}_{3}$ & 5.68 & 162 & 2.0 & 831 & - & \\
\hline$\left(\mathrm{Na}_{0.5} \mathrm{Bi}_{0.5}\right) 0.94-6 \mathrm{BaTiO}_{3}+0.5 \mathrm{~mol} \% \mathrm{CeO}_{2}+0.75 \mathrm{~mol} \% \mathrm{La}_{2} \mathrm{O}_{3}$ & 5.69 & 65 & 2.4 & 310 & - & \\
\hline$\left(\mathrm{Na}_{0.5} \mathrm{Bi}_{0.5}\right)_{0.92}-\mathrm{Ba}_{0.08} \mathrm{TiO}_{3}+x \mathrm{~mol} \% \mathrm{MnCO}_{3}$ & - & 160 & - & - & 243 & {$[52]$} \\
\hline
\end{tabular}


decreasing the dissipation factor. $\mathrm{Ce}^{3+}$ with a radius of $1.18 \AA$ occupies the $\mathrm{A}$-site as $\mathrm{Ba}^{2+}$ in the BNBT lattice and functions as a donor leading to some A-site vacancies. Meanwhile, $\mathrm{Ce}^{4+}$ with a radius of $0.94 \AA$ goes into the $\mathrm{Ti}^{4+}$ site and changes the space charge. $\mathrm{La}_{2} \mathrm{O}_{3}$ is a typical soft additive for PZT ceramic occupying a $\mathrm{Bi}^{3+}$ site or a $\mathrm{Ba}^{2+}$ site [28].

Effect of $M n$ The maximum value of the piezoelectric constant was $160 \mathrm{pC} / \mathrm{N}$ for BNBT doped with $0.56 \mathrm{~mol} \%$ $\mathrm{Mn}$ at room temperature [55]. From the table, it can also be seen that with increasing the amount of the dopant, the $T_{\mathrm{c}}$ decreases rapidly. When the amount of $\mathrm{Mn}$ is lower than $0.56 \mathrm{~mol} \%$, the increase in piezoelectric properties is partly due to the decrease of tetragonality of BNBT. Additionally, the incorporation of smaller cations in a normal perovskite structure causes the slack of lattice and enhances the motion of $90^{\circ}$ domains. When the amount of $\mathrm{Mn}$ is over $2.6 \mathrm{~mol} \%$, it is supersaturated in the lattice of BNBT and the excess of $\mathrm{Mn}$ ions are accumulated in the grain boundaries, resulting in the pinning effect of the domain. Ichinose and Udagawa have studied that the piezoelectric property of $\left(\mathrm{Bi}_{0.5} \mathrm{Na}_{0.5}\right)_{0.87}\left(\mathrm{Sr}_{0.5} \mathrm{Ca}_{0.5}\right)_{0.13} \mathrm{TiO}_{3}$ system was close to MPB composition from the view point of lead-free piezoelectric materials. $\mathrm{MnO}$ was added up to $1 \mathrm{wt} \%$ to this system in order to improve the electromechanical and mechanical properties of the system [56].

$\mathrm{Bi}_{0.5}\left(\mathrm{Na}_{0.5}, \mathrm{~K}_{0.5}\right) \mathrm{TiO}_{3}$ system

A number of lead-free piezoelectric ceramic materials have been developed to replace the PZT-based ceramics for environmental protection [57]. However, BNT still cannot replace PZT-based ceramics due to large coercive field and high conductivity. Recently, many researchers have investigated the effects of small amount of dopants (cation modifications) into $\mathrm{BNT}$ ceramics such as $\mathrm{Ba}, \mathrm{Pb}, \mathrm{Ca}, \mathrm{Sr}$, $\mathrm{Ce}, \mathrm{Se}, \mathrm{NaNbO}_{3}$, etc. and successfully overcome the problems mentioned above.

Jhang et al. investigated the microstructure and electrical properties of $\mathrm{Bi}$-compensated BNT-BKT ceramics sintered at $1110-1170{ }^{\circ} \mathrm{C}[58,59]$. Increasing sintering temperatures enhanced the grain growth, densification, and improvement of piezoelectric and ferroelectric properties.
However, as the temperature was increased to $1170{ }^{\circ} \mathrm{C}$, the piezoelectric properties deteriorated seriously. An MPBlike phase transition from tetragonal to rhombohedral symmetry was found in BNKT20 and BNKT22 specimens sintered between 1150 and $1170{ }^{\circ} \mathrm{C}$. Enhanced electrical properties were obtained for the BNKT22 samples sintered at an optimal temperature of $1150{ }^{\circ} \mathrm{C}$, in which $d_{33}, P_{\mathrm{r}}$, and $K$ were $192 \mathrm{pC} / \mathrm{N}, 19.5 \mu \mathrm{C} / \mathrm{cm}^{2}$, and 1007 , respectively.

\section{Effect of Strontium (Sr)}

Yoo et al. studied the variations of $\mathrm{Sr}$ substitution on leadfree $\mathrm{Bi}_{0.5}\left(\mathrm{Na}_{0.84} \mathrm{~K}_{0.16}\right)_{0.5} \mathrm{TiO}_{3}$ system [60] and concluded that the crystal structure of the specimen moved from tetragonal to tetragonal-rhombohedral MPB with 4-6 mol\% $\mathrm{Sr}$ addition. The piezoelectric constant, $d_{33}$ was $185 \mathrm{pC} / \mathrm{N}$ (Table 9). They also studied the effect of $\mathrm{La}_{2} \mathrm{O}_{3}$ on the piezoelectric and dielectric properties of this leadfree system and concluded that with increasing the amount of $\mathrm{La}_{2} \mathrm{O}_{3}$, the density and dielectric constant increased up to $0.9 \mathrm{wt} \% \mathrm{La}_{2} \mathrm{O}_{3}$ and decreased above it [27, 61].

\section{Effect of $\mathrm{NaNbO}_{3}$}

$\mathrm{Li}$ and his coworkers investigated a ternary system of BNT-BKT-NN and studied the effects of NN on crystal structure, dielectric, ferroelectric, and piezoelectric properties [46]. It can be found from Table 10 that the $d_{33}$ value decreased with the amount of $\mathrm{NaNbO}_{3}$ and the relative low values were located at $x=8 \mathrm{~mol} \%$. This was due to a phase distortion from rhombohedral to cubic phase. In contrast with BNT-NN binary system, the $d_{33}$ of BNTBKT-NN ternary system are higher.

$\mathrm{BNT}-\mathrm{Ba}(\mathrm{Ti}, \mathrm{Zr}) \mathrm{O}_{3}$ system

It is generally known that BNT systems have higher $T_{\mathrm{c}}$ than $\mathrm{BaTiO}_{3}$ systems. Many scientists have been devoted to improving the piezoelectric properties of BNT-based ceramics. One of them reported that $\mathrm{Ba}(\mathrm{Ti}, \mathrm{Zr}) \mathrm{O}_{3}$ (abbreviated as BZT) system has a good piezoelectric constant equal to $236 \mathrm{pC} / \mathrm{N}$ at room temperature [62]. Hence a binary system of BNT-BZT was studied and the properties at the MPB were investigated. Dense BNT-BZT ceramics

Table 9 Properties of $\mathrm{Bi}_{0.5}\left(\mathrm{Na}_{0.84} \mathrm{~K}_{0.16}\right)_{0.5} \mathrm{TiO}_{3}-x \mathrm{SrTiO}_{3}$ system

\begin{tabular}{llllll}
\hline Composition & Density $(\mathrm{g} / \mathrm{cc})$ & $d_{33}(\mathrm{pC} / \mathrm{N})$ & $K$ & $T_{\mathrm{c}}\left({ }^{\circ} \mathrm{C}\right)$ & References \\
\hline $\mathrm{Bi}_{.5}\left(\mathrm{Na}_{0.84} \mathrm{~K}_{0.16}\right)_{0.5} \mathrm{TiO}_{3}+x \mathrm{SrTiO}_{3}$ & & & & & {$[57]$} \\
$\quad x=0.04$ & 5.64 & 185 & 868 & 292 & \\
$\quad x=0.06$ & & 205 & & & \\
$0.96 \mathrm{Bi}_{.5}\left(\mathrm{Na}_{0.84} \mathrm{~K}_{0.16}\right)_{0.5} \mathrm{TiO}_{3}+0.04 \mathrm{SrTiO}_{3}+0.2 \mathrm{wt} \% \mathrm{La}_{2} \mathrm{O}_{3}$ & 5.75 & 215 & 768 & 320 & {$[58]$} \\
\hline
\end{tabular}


Table 10 Properties of $\mathrm{Bi}_{0.5}\left(\mathrm{Na}_{0.5}, \mathrm{~K}_{0.5}, \mathrm{TiO}_{3}-\mathrm{NaNbO}_{3}\right.$ system

\begin{tabular}{lccrr}
\hline Composition & $d_{33}(\mathrm{pC} / \mathrm{N})$ & Tan $\delta(\%)$ & $K$ & References \\
\hline $\mathrm{Na}_{0.5} \mathrm{Bi}_{0.5} \mathrm{TiO}_{3}-\mathrm{K}_{0.5} \mathrm{Bi}_{0.5} \mathrm{TiO}_{3}-\mathrm{NaNbO}_{3}$ & 71 & - & - & {$[43]$} \\
$0.88 \mathrm{Na}_{0.5} \mathrm{Bi}_{0.5} \mathrm{TiO}_{3}-12 \mathrm{~K}_{0.5} \mathrm{Bi}_{0.5} \mathrm{TiO}_{3}$ (NKBTN0) & 100 & 0.0299 & 575 & {$[43]$} \\
$\mathrm{NKBTN8}$ & 100 & 0.0631 & 1237 & {$[43]$} \\
\hline
\end{tabular}

Table 11 Properties of BNT-BZT system

\begin{tabular}{|c|c|c|c|c|c|c|}
\hline Composition & Density (g/cc) & $d_{33}(\mathrm{pC} / \mathrm{N})$ & $\operatorname{Tan} \delta(\%)$ & $K$ & $T_{\mathrm{c}}\left({ }^{\circ} \mathrm{C}\right)$ & References \\
\hline BNT & 5.32 & 64 & 1.752 & 302.6 & 310 & {$[60]$} \\
\hline BNT-BZT3 & 5.76 & 79 & 1.765 & 345.6 & 236 & {$[60]$} \\
\hline BNT-BZT6 & 5.72 & 107 & 2.185 & 844.6 & 236 & [60] \\
\hline BNT-BZT9 & 5.82 & 147 & 2.636 & 881.4 & 244 & {$[60]$} \\
\hline BNT-BZT12 & 5.69 & 112 & 2.980 & 788.7 & 259 & {$[60]$} \\
\hline
\end{tabular}

$\left(5.69-5.82 \mathrm{~g} / \mathrm{cm}^{3}\right)$ were obtained because the preparation processes were modified, in which BNT and BZT powders were synthesized separately. For BNT-BZT binary system, a high piezoelectric constant, $d_{33}=147 \mathrm{pC} / \mathrm{N}$ was obtained at the composition near MPB. The pure BNT ceramic showed a high $T_{\mathrm{c}}$ value of $310^{\circ} \mathrm{C}$ (Table 11). A small amount of BZT addition decreases the $T_{\mathrm{c}}$ greatly. However, when the addition of BZT exceeds 9 mol\% there is a small rise in the $T_{\mathrm{c}}$. The reason for this small shift is not clear at present, but BZT addition may also influence the evolution of sintered microstructure, hence Curie temperature in addition to its chemical effect.

\section{$\mathrm{Bi}(\mathrm{Na}, \mathrm{K}, \mathrm{Li}) \mathrm{TiO}_{3}$ system}

Lin et al. did further investigation on BNT system by substituting $\mathrm{Na}^{+}$in BNT by $\mathrm{K}^{+}$and $\mathrm{Li}^{+}$and finally invented $\mathrm{Bi}(\mathrm{Na}, \mathrm{K}, \mathrm{Li}) \mathrm{TiO}_{3}$ ceramics as a new group of BNT-based lead-free system [63]. Under this consideration, a new system of $\mathrm{Bi}(\mathrm{Na}, \mathrm{K}, \mathrm{Li})-\mathrm{BT}$ multi component lead-free piezoelectric ceramics was also proposed [64]. Table 12 indicates that the ceramics were well sintered at $1100-1150{ }^{\circ} \mathrm{C}$ for $2-3 \mathrm{~h}$. The ceramics with higher the

Table 12 Properties of $\mathrm{Bi}(\mathrm{Na}, \mathrm{K}, \mathrm{Li}) \mathrm{TiO}_{3}$ system

\begin{tabular}{lllll}
\hline Composition & $\begin{array}{l}d_{33} \\
(\mathrm{pC} / \mathrm{N})\end{array}$ & $\begin{array}{l}\mathrm{Tan} \delta \\
(\%)\end{array}$ & $K$ & References \\
\hline$\left[\mathrm{Bi}_{0.5}\left(\mathrm{Na}_{1-x-y} \mathrm{~K}_{x} \mathrm{Li}_{y}\right)_{0.5}\right] \mathrm{TiO}_{3}$ & & & & {$[61]$} \\
{$\left[\mathrm{Bi}_{0.5}\left(\mathrm{Na}_{0.6} \mathrm{~K}_{0.35} \mathrm{Li}_{0.05}\right)_{0.5}\right] \mathrm{TiO}_{3}$} & 120 & 5.7 & 1753 & {$[61]$} \\
{$\left[\mathrm{Bi}_{0.5}\left(\mathrm{Na}_{0.7} \mathrm{~K}_{0.25} \mathrm{Li}_{0.05}\right)_{0.5}\right] \mathrm{TiO}_{3}$} & 145 & 4.1 & 1276 & {$[61]$} \\
{$\left[\mathrm{Bi}_{0.5}\left(\mathrm{Na}_{0.65} \mathrm{~K}_{0.25} \mathrm{Li}_{0.1}\right)_{0.5}\right] \mathrm{TiO}_{3}$} & 100 & 4.9 & 1109 & {$[61]$} \\
{$\left[\mathrm{Bi}_{0.5}\left(\mathrm{Na}_{0.7} \mathrm{~K}_{0.15} \mathrm{Li}_{0.15}\right)_{0.5}\right] \mathrm{TiO}_{3}$} & 41 & - & 1179 & {$[62]$} \\
{$\left[\mathrm{Bi}_{0.5}\left(\mathrm{Na}_{0.75} \mathrm{~K}_{0.05} \mathrm{Li}_{0.2}\right)_{0.5}\right] \mathrm{TiO}_{3}$} & 51 & - & 800 & {$[62]$} \\
\hline
\end{tabular}

amount of $\mathrm{K}^{+}$and lower the amount of $\mathrm{Li}^{+}$and $\mathrm{Na}^{+}$have relatively larger piezoelectric constant $d_{33}(143 \mathrm{pC} / \mathrm{N})$. It can be concluded that with increasing the value of $\mathrm{K}^{+} / \mathrm{Li}^{+}$ ratio, the piezoelectric constant increases. The amount of $\mathrm{K}^{+}$also greatly influences the dielectric constant of the ceramics [63].

The electrical properties of $\left.\left[\mathrm{Bi}_{1-z}\left(\mathrm{Na}_{1-x-y-z}\right) \mathrm{K}_{x} \mathrm{Li}_{y}\right)_{0.5}\right]$ $\mathrm{Ba}_{z} \mathrm{TiO}_{3}(\mathrm{BN}-x / y / z)$ multicomponent lead-free piezoelectric system proposed by Lin et al. by the conventional ceramic technique were studied [64] (Table 13). The piezoelectric constant $d_{33}$ has a maximum value of $178 \mathrm{pC} / \mathrm{N}$ at $x=0.15$. The maximum values of $d_{33}(198 \mathrm{pC} / \mathrm{N})$ of the BN-0.15/0.10/z ceramics occur at $z=0.02$. The ceramics with $x=0.15-0.20$ and $z=0.01-0.04$ provide better piezoelectric properties, which may be attributed to the compositions near the MPB where the number of spontaneous polarization directions increases [65]. However, the addition of Li significantly improves the sintering performance, decreases the sintering temperature of BNT ceramics, and greatly assists in densification of BNT-based ceramics. Also, Lam et al. synthesized soft lead-free piezoelectric materials in the system BNKLT 1-3 composites [66].

\section{BNT-BKT-BT system}

Barium titanate, $\mathrm{BaTiO}_{3}$ (BT), and potassium bismuth titanate, $\mathrm{Bi}_{0.5} \mathrm{~K}_{0.5} \mathrm{TiO}_{3}(\mathrm{BKT})$ are well-known lead-free piezoelectric materials with a tetragonal phase. The phase relation of the BNT-BT-BKT system is shown in Fig. 2. Takenaka and Sasaki et al. reported the binary systems of BNT-BT and BNT-BKT piezoelectric ceramics respectively [26, 27, 67].

$\mathrm{Li}$ et al. have demonstrated that preferred piezoelectric properties have been obtained by adding BKT and BT into 
Table 13 Properties of $\mathrm{Bi}(\mathrm{Na}, \mathrm{K}, \mathrm{Li}) \mathrm{TiO}_{3}-\mathrm{BaTiO}_{3}$ system

\begin{tabular}{|c|c|c|c|c|}
\hline Composition & $d_{33}(\mathrm{pC} / \mathrm{N})$ & $\operatorname{Tan} \delta(\%)$ & $K$ & References \\
\hline $\left.\mathrm{Bi}_{1-z}\left(\mathrm{Na}_{1-x-y-z} \mathrm{~K}_{x} \mathrm{Li}_{y}\right)\right]_{5} \mathrm{Ba}_{z} \mathrm{TiO}_{3(\mathrm{BN}-x / y / z)}$ & & & & {$[27]$} \\
\hline $\mathrm{BN}-0.15 / 0.10 / 0.02$ & 198 & 3.7 & 1170 & \\
\hline $\mathrm{BN}-0.15 / 0.075 / 0.02$ & 205 & 3.4 & 1040 & \\
\hline $\mathrm{BN}-0.15 / 0.075 / 0.01$ & 178 & 3.1 & 735 & \\
\hline $\mathrm{BN}-0.10 / 0.075 / 0.01$ & 130 & 2.1 & 550 & \\
\hline
\end{tabular}

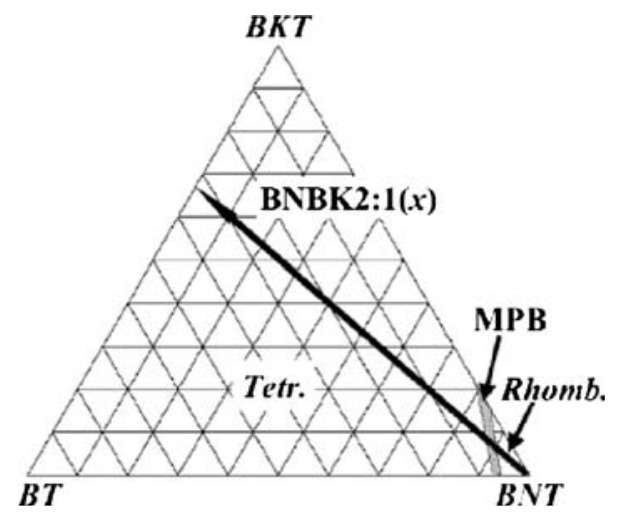

Fig. 2 Phase relation of $\left(\mathrm{Bi}_{0.5} \mathrm{Na}_{0.5}\right) \mathrm{TiO}_{3}-\mathrm{BaTiO}_{3}-\left(\mathrm{Bi}_{0.5} \mathrm{~K}_{0.5}\right) \mathrm{TiO}_{3}$ (BNBK) system [10]

BNT to form BNT-BKT-BT ternary system [68]. They also investigated a $(1-3 x)$ BNT $-2 x$ BKT $-x$ BT ternary system by keeping the BKT and BT ratio constant (Table 14). A conventional ceramic fabrication technique was used to prepare them. The piezoelectric and dielectric properties were also reported [69]. They concluded that the dielectric constant and $d_{33}$ increases with increasing $x$, reaches the maximum value of $150 \mathrm{pC} / \mathrm{N}$ at $x=0.035$ and then decreases. These properties demonstrate that the compositions near the MPB have relatively high piezoelectric and electromechanical activities due to increase in the number of possible spontaneous polarization and due to the coexistence of rhombohedral and tetragonal phases.

$\mathrm{Li}$ et al. also prepared $(1-5 x) \mathrm{BNT}-4 x \mathrm{BNT}-x \mathrm{BT}$ ceramic by conventional ceramic fabrication technique [49]. The piezoelectric and ferroelectric properties of these ceramics were studied. They were of the conclusion that the piezoelectric constant $d_{33}$ attains a maximum value of $149 \mathrm{pC} / \mathrm{N}$ at $x=0.03$. This property demonstrates that the compositions near the MPB have relatively high piezoelectric activities.

Lead-free piezoelectric ceramic $0.90\left(\mathrm{Bi}_{0.5} \mathrm{Na}_{0.5}\right) \mathrm{TiO}_{3}-$ $0.05\left(\mathrm{Bi}_{0.5} \mathrm{~K}_{0.5}\right) \mathrm{TiO}_{3}-0.05 \mathrm{BaTiO}_{3}$ (abbreviated as BNTBKT-BT5) has been used recently as the driving element in a cymbal actuator with titanium end caps. It was found that the lead-free ceramic cymbal actuator has reasonable piezoelectric coefficients and low density. Hence its performance was comparable to those fabricated using hard PZT ceramic [70].

Alkali niobates

\section{$\mathrm{KNbO}_{3}$-based ceramics}

Matthias discovered ferroelectricity in potassium niobate, $\mathrm{KNbO}_{3}$ [71]. Alternative lead-free materials of the perovskite family with the general formula, $\mathrm{ANbO}_{3}(A=$ alkali metal) were proposed by researchers in the 1950 s and 1960s [9]. $\mathrm{KNbO}_{3}(\mathrm{KN})$ has an orthorhombic symmetry at room temperature, and $\mathrm{KN}$ single crystals are known to have high piezoelectric activities. It is known that $\mathrm{KNbO}_{3}$ and related compounds show a high Curie temperature $\left(T_{\mathrm{c}}=435^{\circ} \mathrm{C}\right)$ and good piezoelectric properties.

$\mathrm{KNbO}_{3}-\mathrm{NaNbO}_{3}$ system

( $\mathrm{K}, \mathrm{Na}) \mathrm{NbO}_{3}$ (abbreviated as $\mathrm{KNN}$ ) is considered as one of the most promising candidates for lead-free piezoelectric ceramics. It is a solid solution of ferroelectric $\mathrm{KNbO}_{3}$ and antiferroelectric $\mathrm{NaNbO}_{3}$, exhibiting very high Curie temperature $\left(T_{\mathrm{c}}=420{ }^{\circ} \mathrm{C}\right)$, good ferroelectric properties $\left(P_{\mathrm{r}}=33 \mu \mathrm{C} / \mathrm{cm}^{2}\right)$, and large electromechanical coupling

Table 14 Properties of $\mathrm{Bi}(\mathrm{Na}, \mathrm{K}) \mathrm{TiO}_{3}-\mathrm{BaTiO}_{3}$ system

\begin{tabular}{lcl}
\hline Composition & $d_{33}(\mathrm{pC} / \mathrm{N})$ & References \\
\hline $\mathrm{Na}_{0.5} \mathrm{Bi}_{0.5} \mathrm{TiO}_{3}-\mathrm{K}_{0.5} \mathrm{Bi}_{0.5} \mathrm{TiO}_{3}-\mathrm{BaTiO}_{3}$ & 150 & \\
$(1-3 x) \mathrm{NBT}-2 x \mathrm{KBT}-x \mathrm{Bt}$ & & \\
$(x=0.01,0.02,0.025,0.03,0.035,0.04)$ at $x=0.035$ & 145 & {$[46]$} \\
$(1-5 x) \mathrm{NBT}-4 x \mathrm{KBT}-x \mathrm{BT}$ & & \\
$(x=0,0.01,0.02,0.024,0.028,0.03,0.032)$ at $x=0.03$ & \\
\hline
\end{tabular}


Fig. 3 Phase diagram for the system $\mathrm{KNbO}_{3}-\mathrm{NaNbO}_{3}[2,9]$

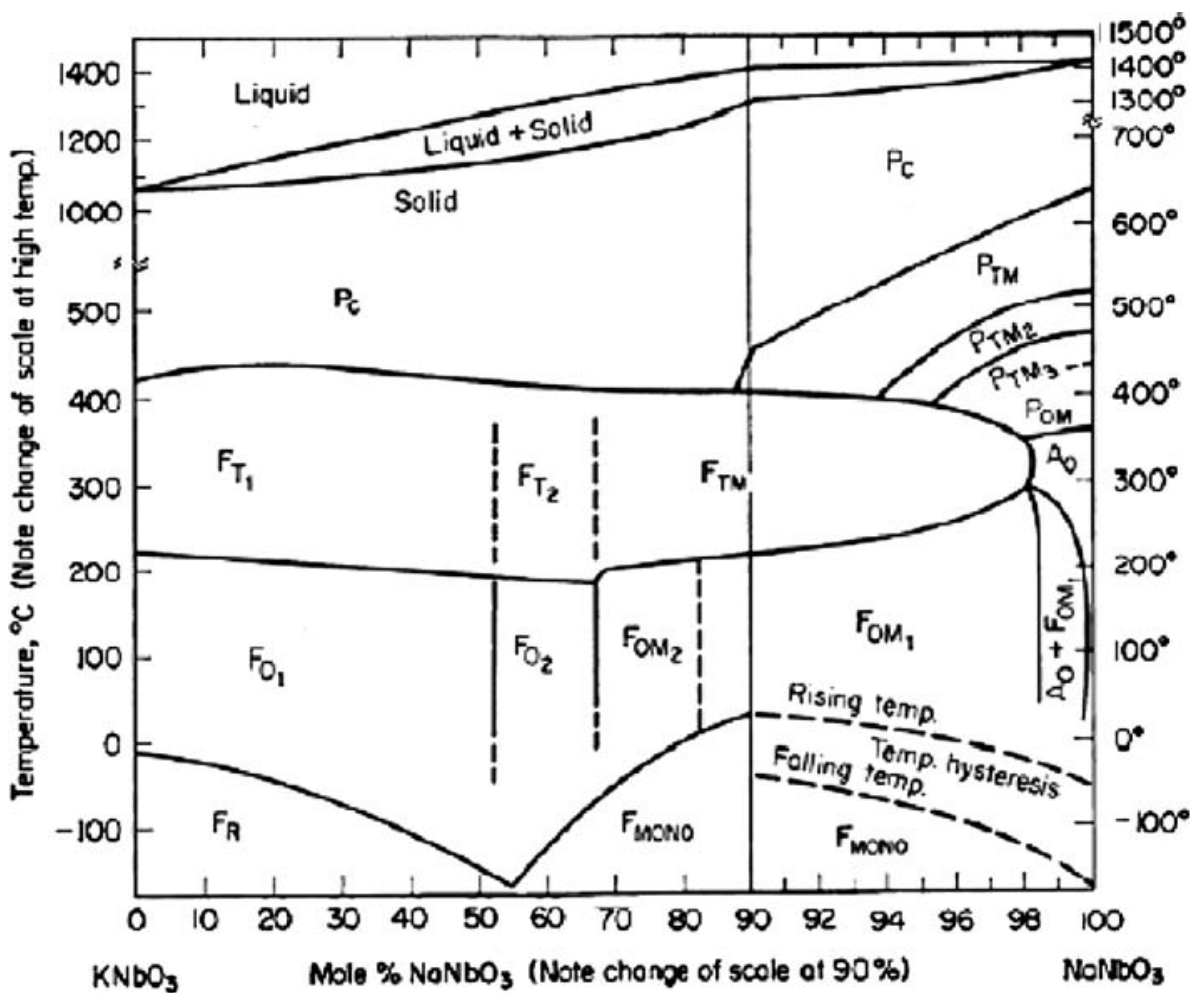

factors [72]. The phase diagram for the KNN system is shown in Fig. 3. The piezoelectric data for the air-fired samples are in the range of $d_{33}=80 \mathrm{pC} / \mathrm{N}$ and density of the sample is around $4.25 \mathrm{~g} / \mathrm{cc}$ [2]. One of the main obstacles for the development of potassium sodium niobates $(\mathrm{KNN})$ as a commercial piezoceramic material by conventional method is the difficulty in processing and densification. Further more; the volatility of potassium oxide makes it difficult to maintain stoichiometry. To optimize the processing conditions and to obtain reproducible properties, KNN ceramics were doped with suitable materials. Matsubara et al. [73] and Seo et al. [74] found that the addition of $\mathrm{CuO}$ greatly enhanced the sinterability of KNN-based ceramics. $\mathrm{CuO}$ is often used because of its low melting point and formation of liquid phase.

Park et al. [75] elaborately studied the effect of $\mathrm{CuO}$ on KNN ceramics. They observed that addition of $\mathrm{CuO}$ decreases the sintering temperature of KNN below $1000{ }^{\circ} \mathrm{C}$ in order to prevent the $\mathrm{Na}_{2} \mathrm{O}$ evaporation and to eventually improve the piezoelectric properties by increasing their polling efficiency. When a small amount of $\mathrm{CuO}$ was added, a dense microstructure with increased grain size was developed. Liquid-phase sintering was considered to have been responsible for the development of the dense microstructure. The $\mathrm{Cu}^{2+}$ ion replaced the $\mathrm{Nb}^{5+}$ ion and produced an oxygen vacancy to maintain the charge neutrality. A defect dipole consisting of the $\mathrm{Cu}^{2+}$ ion and oxygen vacancy provided the pinning effect, which eventually transformed the NKN ceramics into the hard materials. The Curie temperature and Ec were slightly increased with $\mathrm{CuO}$ addition.

Bernard et al. [76] found that the densification of KNN ceramics can be improved by the addition of a small amount (from 0.5 to 4 mass $\%$ ) germanate, which melts at around $700{ }^{\circ} \mathrm{C}$. Germanate-modified $\mathrm{KNN}$ ceramics can be sintered to high density (95.6\% TD) at $1000{ }^{\circ} \mathrm{C}$ without degrading the piezoelectric properties.

Egerton and co-workers reported the electrical properties of potassium sodium niobates, $\mathrm{KNbO}_{3}-\mathrm{NaNbO}_{3}$ system $(\mathrm{KNN})$ in which they indicated relatively low dielectric constants over a wide compositional range. Hence to achieve sufficient densification, hot-pressed KNN ceramics ( $\sim 99 \%$ of theoretical density) have been reported to possess high Curie temperature $\left(T_{\mathrm{c}}=420{ }^{\circ} \mathrm{C}\right)$, large piezoelectric longitudinal response $\left(d_{33}=160 \mathrm{pC} / \mathrm{N}\right)$, and high planar coupling coefficient $\left(k_{\mathrm{p}}=45\right)$. KNN samples have been prepared by conventional air sintering in order to reach high densities over 95\% which yielded superior piezoelectric properties $\left(d_{33}=100 \mathrm{pC} / \mathrm{N}\right)$ than those obtained by the same method as reported previously [77]. It is important to note, $\mathrm{KNN}$ material prepared by spark plasma sintering reported significantly higher dielectric and piezoelectric properties than those prepared by conventional method ( $K \sim 700$ and $d_{33} \sim 148 \mathrm{pC} / \mathrm{N}$ ) [78, 79]. Recently, Saito et al. fabricated textured-based KNN 
Table 15 Comparison of properties of alkali niobates obtained by different processing methods

\begin{tabular}{|c|c|c|c|c|}
\hline Processing methods & Density $(\mathrm{g} / \mathrm{cc})$ & $\% \mathrm{TD}$ & $d_{33}(\mathrm{pC} / \mathrm{N})$ & $k_{\mathrm{p}}$ \\
\hline Air-sintered (Jaeger-Egerton) $\mathrm{K}_{0.5} \mathrm{Na}_{0.5} \mathrm{NbO}_{3}$ & 4.25 & 94.24 & 80 & 0.36 \\
\hline Air-sintered (Kosec) $\mathrm{K}_{0.5} \mathrm{Na}_{0.5} \mathrm{NbO}_{3}$ & 4.20 & 93.13 & - & 0.23 \\
\hline Air-sintered H. (Birol) $\mathrm{K}_{0.5} \mathrm{Na}_{0.5} \mathrm{NbO}_{3}$ & 4.30 & 95.3 & 110 & 0.39 \\
\hline Hot-pressed (Jaeger-Egerton) $\mathrm{K}_{0.5} \mathrm{Na}_{0.5} \mathrm{NbO}_{3}$ & 4.46 & 98.89 & 160 & 0.45 \\
\hline Hot-forged (Schultze) $\mathrm{K}_{0.5} \mathrm{Na}_{0.5} \mathrm{NbO}_{3}+4 \mathrm{~mol} \% \mathrm{Ba}$ & 4.28 & 94.90 & 115 & 0.37 \\
\hline Reactive grain growth (Saito et al.) & - & - & 416 & - \\
\hline
\end{tabular}

ceramics by the reactive grain-growth method which produced $d_{33}$ value as high as $\sim 416 \mathrm{pC} / \mathrm{N}$ [80]. Comparisons of properties of alkali niobates $\left(\mathrm{ANbO}_{3}\right)$ obtained by different processing methods are given in Table 15 .

Effect of dopants on KNN-based ceramics Potassium sodium niobate is a promising lead-free material with low dielectric constant and high electromechanical coupling coefficient. However, it is difficult to prepare KNN ceramics with high density by conventional sintering technique. Sintering may be activated by the addition of $\mathrm{Nb}^{5+}$ or $\mathrm{Mg}^{2+}$ ions in the crystal lattice thereby producing highdensity sample [81-84].

(i) Effect of $\mathrm{LiTaO}_{3}$ and $\mathrm{LiSbO}_{3}$ : The effect of incorporated $\mathrm{LiTaO}_{3}$ on the structure, phase transition behavior and electrical properties of the KNN system have been studied [85-90]. It was established that Ta substitution for $\mathrm{Nb}$, changes the properties of $\mathrm{KNbO}_{3}$ and the authors also demonstrated that small amounts of $\mathrm{Ta}$ for $\mathrm{Nb}$ could enhance the piezoelectric properties of KNN ceramics [72, 91]. Saito et al. [92] also developed a lead-free system containing a blend of alkaline niobate $\left(T_{\mathrm{c}}=415^{\circ} \mathrm{C}\right)$ based solid solution with $\mathrm{LiTaO}_{3}\left(T_{\mathrm{c}}=615^{\circ} \mathrm{C}\right)$. This system gave good piezoelectric response with a $d_{33}$ of $230 \mathrm{pC} / \mathrm{N}$. Addition of $\mathrm{LiSbO}_{3}$ to the above system increased the $d_{33}$ to $373 \mathrm{pC} / \mathrm{N}$ [80]. Many authors have been studied the effect of $\mathrm{LiSbO}_{3}$ (LS) on pure KNN ceramics [93-95]. Yang et al. [93] studied the effect of LS on pure KNN ceramics and reported that increasing the LS content, the $d_{33}$ and $k_{\mathrm{p}}$ values of the ceramics initially increased, and then began to decrease at higher LS concentration. In addition, dielectric study revealed that $T_{\mathrm{c}}$ shifted toward the lower temperature regions and a normal ferroelectric KNN-based ceramics changed to relaxor ferroelectric by increasing LS content. The KNN-LS ceramics are promising lead-free piezoelectric materials for electromechanical transducer applications. Effect of other ions such as Ag, $\mathrm{Nb}, \mathrm{Ta}, \mathrm{Bi}, \mathrm{Cu}, \mathrm{Ca}$, etc. and combination two or three cations on KNN-LS ceramics were also studied by many authors [96-108] and promising results were reported. Wang et al. reported that addition of $\mathrm{Ag}$ in $\mathrm{KNN}-\mathrm{LiTaO}_{3}$ ceramics increases the Curie temperature $\left(T_{\mathrm{c}}=438^{\circ} \mathrm{C}\right)$ and piezoelectric properties $\left(d_{33}=252 \mathrm{pC} / \mathrm{N}\right)$ of the ceramic by normal sintering technique [109].

(ii) Effect of alkaline earth ions: The effect of low amount of alkaline earth dopants, (0.5 at.\%) $\mathrm{Mg}^{2+}, \mathrm{Ca}^{2+}$, $\mathrm{Sr}^{2+}$, and $\mathrm{Ba}^{2+}$ on $\mathrm{KNN}$ solid solution synthesis, sinterability, and functional response of corresponding ceramics was also studied by different authors [110-113]. They were chosen on the basis of the similarity of their ionic radii to those of $\mathrm{K}^{+}$and $\mathrm{Na}^{+}$. Chang et al. [114] observed that adding $\mathrm{Ca}^{2+}$ and $\mathrm{Sr}^{2+}$ to $\mathrm{KNN}$ can make the cell parameters increase, promote densification, decrease the phase transition temperatures, and improve the electrical properties. However, adding $\mathrm{Mg}^{2+}$ to $\mathrm{KNN}$ can lower the cell parameters and density, increase $T_{\mathrm{c}}$, and seriously deteriorate the electrical properties. Adding $\mathrm{Ba}^{2+}$ to $\mathrm{KNN}$ can increase the cell parameters, decrease the density, decrease the phase transition temperatures, and also significantly deteriorate electrical properties.

(iii) Effect of $\mathrm{BaTiO}_{3}: \mathrm{BaTiO}_{3}$ is one of the typical ferroelectric materials showing large piezoelectricity, but its low $T_{\mathrm{c}}$ limits the application. However, by the addition of $\mathrm{BaTiO}_{3}$ to $\mathrm{Na}_{1-x} \mathrm{~K}_{x} \mathrm{NbO}_{3}$, it could be anticipated that the solid solution would show a relatively high $T_{\mathrm{c}}$ with piezoelectricity comparable to $\mathrm{BaTiO}_{3}[115,116]$.

\section{Non-perovskite structured lead-free ferroelectrics}

Bismuth layer-structured ferroelectrics

Aurivillius type structure oxides with general formula $\mathrm{Bi}_{2} \mathrm{~A}_{n-1} \mathrm{~B}_{n} \mathrm{O}_{3 n+3}$, which consist of $n$-perovskite layers $\left[\mathrm{A}_{n-1} \mathrm{~B}_{n} \mathrm{O}_{3 n+1}\right]^{2-}$ sandwiched between bismuth oxygen sheets $\left[\mathrm{Bi}_{2} \mathrm{O}_{2}\right]^{2+}$ come under BLSF. The perovskite layer can be a one, two, three, or more perovskite unit thick. Each of these results in a separate structure type, but has the perovskite layer-bismuth oxide layer alteration [117]. Possible substitutions into Bi-site of bismuth oxide layer by other $p$-cations that have a stereo-chemical active lone pair of electrons, such as $\mathrm{Pb}^{2+}, \mathrm{Sb}^{3+}$, and $\mathrm{Te}^{4+}$ have been 
reported. $\mathrm{Bi}_{3} \mathrm{NbTiO}_{9}$ is an example of such compound because of its high $T_{\mathrm{c}}\left(914{ }^{\circ} \mathrm{C}\right)$, however it posses very weak piezoelectric effects. The maximum $d_{33}$ reported for any of these layer structure compositions is $25 \mathrm{pC} / \mathrm{N}$ [2]. The family of BLSF is very attractive from the viewpoint of their applications as electronic materials such as dielectrics, piezoelectric, and/or pyroelectric. BLSF are characterized by their low dielectric constant, high Curie temperature $\left(T_{\mathrm{c}}\right)$, and large anisotropy in the electromechanical coupling factor. Therefore, the BLSF ceramics are seen as superior candidates for lead-free piezoelectric applications for high $T_{\mathrm{c}}$ piezoelectric sensors, filters, resonators, and/or pyroelectric sensors with large figures of merit [10].

\section{$\mathrm{Bi}_{4} \mathrm{Ti}_{3} \mathrm{O}_{12}$-based BLSF system}

Bismuth titanate, $\mathrm{Bi}_{4} \mathrm{Ti}_{3} \mathrm{O}_{12}$, is a typical well-known BLSF. Concerning the anisotropy, Cross and Pohanka [118] reported that BiT single crystal has good piezoelectricity. However, it is difficult to measure piezoelectric properties on the BiT single crystal because of its thin structure. On the other hand, fully reliable piezoelectric properties of BiT ceramics have not been reported because of some problems such as the low resistivity and the large coercive field. To solve these problems, $\mathrm{Nb}^{5+}$ and $\mathrm{V}^{5+}$ ions were doped into BiT ceramic to obtain higher resistivity [22].

\section{$\mathrm{Bi}_{3} \mathrm{TiTaO}_{9}$-based BLSF system}

Bismuth layer-structured ferroelectrics of the type, $\mathrm{Bi}_{3} \mathrm{TiNbO}_{9}$ and $\mathrm{CaBi}_{2} \mathrm{Ta}_{2} \mathrm{O} 9$, possess very high $T_{\mathrm{c}}$ above $800{ }^{\circ} \mathrm{C}$ [2]. These data suggest that high mechanical quality factor $\left(Q_{\mathrm{m}}\right)$ is obtained by BLSF materials with high $T_{\mathrm{c}}$ making them suitable for electromechanical transducer required to sense strains, vibrations, and noise under severe thermal conditions. By this concept, dielectric, ferroelectric, and piezoelectric properties of $\mathrm{Bi}_{3} \mathrm{TiTaO}_{9}$ (BTT) based solid solution system with a high $T_{\mathrm{c}}$ were also investigated [10]. The authors have studied that in the Srsite substituted compositions, there is a variation of the phase transition temperature with the ionic radius size and the amount of modifier, but no extra peaks in dielectric constant have been observed [119].

Non-perovskites with lead-free tungsten-bronze structure

A number of ferroelectrics of potential commercial importance have the potassium tungsten-bronze $\mathrm{A}_{x} \mathrm{~B}_{2} \mathrm{O}_{6}$ structure. Some examples are $\mathrm{BaNb}_{2} \mathrm{O}_{6}, \mathrm{SrNb}_{2} \mathrm{O}_{6}, \mathrm{Sr}_{x} \mathrm{Ba}_{1-x}$ $\mathrm{Nb}_{2} \mathrm{O}_{6}, \mathrm{AB}_{2} \mathrm{O}_{6}$ type, etc. Piezoelectric ceramics with tungsten-bronze structure are potentially served as sensors in sensing patches, single crystals for electro-optic uses, etc. Matsuo et al. studied the effect of doping $\mathrm{Sr}_{2-x} \mathrm{Ca}_{x-}$ $\mathrm{NaNb}_{5} \mathrm{O}_{15}$ with $\mathrm{La}_{2} \mathrm{O}_{3}$ and concluded that a dielectric constant of 1662 , Curie temperature of $298{ }^{\circ} \mathrm{C}$, spontaneous polarization of $10.7 \mu \mathrm{C} / \mathrm{cm}^{2}$ and piezoelectric constant of $138 \mathrm{pC} / \mathrm{N}$ was obtained, respectively. The piezoelectric properties of the SCNN-based ceramics indicate that they are good candidates for sensor applications [120-123]. The study investigating the electrical properties of dense leadfree piezoelectric ceramics in the $(1-x) \mathrm{Sr}_{2} \mathrm{NaNb}_{5} \mathrm{O}_{15}$ $x \mathrm{Ca}_{2} \mathrm{NaNb}_{5} \mathrm{O}_{15}$ (SCNN) system with $x$ ranging from 0.05 to 0.35 has also been reported. Ferroelectric and piezoelectric properties of SCNN greatly depended on the $\mathrm{Ca}$ content. The composition with $x=0.15$ exhibited piezoelectric constant of $d_{33}=96 \mathrm{pC} / \mathrm{N}$. This study apparently indicates that lead-free SCNN piezoelectric ceramics have potential for electromechanical applications.

\section{Processing methodology of piezoelectric ceramics}

The fabrication of most bulk piezoelectric ceramics starts with powder preparation. The powder is then pressed to the required shapes and sizes, and the green shapes are in turn processed to mechanically strong and dense ceramics. The next steps are machining, electroding, and poling-application of a DC field to orient the dipoles and induce piezoelectricity.

The most common powder preparation is the mixed oxide route. In this process, powder is prepared from the appropriate stoichiometric mixture of the constituent oxides. Mixing of the powders is done by dry ball-milling or wet ball-milling, both methods having advantages and disadvantages: wet ball-milling is faster than dry-milling; however, the disadvantage is the added step of liquid removal. A vibratory mill may be used rather than a conventional ball mill.

Depending on application, various dopants are used to tailor the properties of interest. A-site additives tend to lower the dissipation factor, which affects heat generation, but also lower the piezoelectric coefficients; for this reason, they are mostly used in ultrasonic and other high frequency applications. B-site dopants increase the piezoelectric coefficients but also increase the dielectric constant and loss. They are utilized as actuators in vibration and noise control, benders, optical positioning application, etc.

Apart from the conventional "mixed oxide" method, lead-free piezo-materials are also prepared by various chemical routes such as by sol-gel, wet-chemical route, co-precipitation, etc., similar to the processing methods followed for the synthesis of PZTs. The calcination step is a very crucial step in the processing of PZT ceramics. During calcination organics, water or other volatiles are removed 
and formation of required phases takes place. The crystal structure is confirmed by X-ray diffraction analysis. After calcination, binder was added to the powder and compacted into pellets. They are then sintered at temperatures varying between 1100 and $1200{ }^{\circ} \mathrm{C}$. Electrodes (conducting silver paste) are applied and a strong DC field is used to orient the domains in the polycrystalline ceramic and the dielectric and piezoelectric properties were measured after poling.

This processing technique present many uncertaintiesone problem often encountered is the deviation from stoichiometry. Also, the piezoelectric and dielectric properties generally suffer if there is any lack of homogeneity due to poor mixing. It is important then that the constituent oxides be intimately mixed. More information on the preparation of piezoelectric ceramics can be found in Jaffe et al. [2], and Moulson and Herbert [124] among others. Other processing methods including hydrothermal processing and co-precipitation methods are described in references [125-129].

\section{Critical comments}

Lead-free materials are of interests as new candidates to replace the widely used lead-based ceramics because of their pollution free environmental friendly character during the preparation process. Hence, this research area is of current interest to researchers worldwide.

(i) BNT is considered to an excellent candidate for leadfree piezoelectric ceramics with a high $T_{\mathrm{c}}$ of $320^{\circ} \mathrm{C}$, as well as relatively large remnant polarization, $P_{\mathrm{r}}$ of $38 \mu \mathrm{C} / \mathrm{cm}^{2}$ and coercive field, $E_{\mathrm{c}}$ of $73 \mathrm{kV} / \mathrm{cm}$. Still BNT cannot replace PZT due to its large coercive field and high conductivity. Hence researchers have investigated many dopants into BNT ceramics to solve these problems.

(ii) In addition to that, scientists have developed multicomponent systems, which have higher piezoelectric properties than binary systems. For example, $\mathrm{BaTiO}_{3}, \mathrm{KNbO}_{3}$ combined with a rhombohedral compound to yield a high activity MPB system.

(iii) The density of lead-free piezoelectric materials are approximately half of the density of PZTs; therefore, the effective specific piezo properties per unit weight of lead-free materials are double their actual values when these materials have to be compared with PZTs. For example, a $d_{33}$ value of $150 \mathrm{pC} / \mathrm{N}$ of a lead-free material is nearly equivalent to 280 $300 \mathrm{pC} / \mathrm{N}$ of PZT material.

(iv) Lead-free materials like $\mathrm{BNT}, \mathrm{NaNbO}_{3}, \mathrm{KNbO}_{3}$, etc. were also developed simultaneously along with PZT in the 1950s. But due to the excellent piezoelectric properties exhibited by the PZTs, the researchers were preferred to work on the PZT system; hence, not much work was done on lead-free materials. Even though the initial results on PZT system showed lower piezo properties, the values were largely enhanced after the discovery of MPB, addition of suitable dopants, etc., studied systematically. A similar systematic approach may be required for the enhancement of piezo properties of lead-free materials at least very near to the level of PZTs.

\section{Conclusions}

Lead-free piezoelectric materials with excellent dielectric and piezoelectric properties belonging to the perovskite ferroelectric and bismuth layer-structured (BLSF) ceramics were investigated as superior candidates to reduce environmental damages. The families of sodium potassium niobate and bismuth sodium titanate that come under the perovskite type ceramics seem to be suitable for actuator and high power applications with a piezoelectric constant, $d_{33}>150 \mathrm{pC} / \mathrm{N}$ and a high Curie Temperature, $T_{\mathrm{c}}>$ $200{ }^{\circ} \mathrm{C}$. For high temperature applications $\left(>600^{\circ} \mathrm{C}\right)$, bismuth-layered compounds show good stability of properties and hence they serve as excellent candidates for piezoelectric sensors. In order to replace PZT systems, it is necessary that special features of each lead-free material correspond to required piezoelectric properties for each application.

Acknowledgements The author expresses his sincere gratitude to Mr. M.K. Sridhar, Head, Materials Science Division and Dr. A. R. Upadhya, Director, NAL for their support and encouragement during the course of the study. The author also thanks to M. Sunitha and Benudhar Sahoo for their help in the preparation of the manuscript.

Open Access This article is distributed under the terms of the Creative Commons Attribution Noncommercial License which permits any noncommercial use, distribution, and reproduction in any medium, provided the original author(s) and source are credited.

\section{References}

1. Curie J, Curie P (1880) Bulletin de la Societe Mineralogique de France 3:90

2. Jaffe B, Jaffe H, Cook WR (1971) Piezoelectric ceramics, 1st edn. Academic Press, London

3. Haertling GH (1991) In: Buchanan RC (ed) Piezoelectric and electro-optic ceramics in ceramic materials for electronics, 2nd edn. Marcel Dekker, New York

4. Uchino K (1993) Mater Res Bull 18:42

5. Newnham RE (1998) Functional composites for sensors and actuators: smart materials. The Pennsylvania Academy of Science, PA, USA 
6. Sahoo B, Jaleel VA, Panda PK (2006) Mater Sci Eng B 126:80

7. Sahoo B, Panda PK (2007) J Mater Sci 42:4270. doi:10.1007/ s10853-006-0687-2

8. Yugong W, Zhang H, Zhang Y, Jinyi M, Daohua X (2003) J Mater Sci 38:987

9. Ringgaard E, Wurlitzer T (2005) J Eur Ceram Soc 25:2701

10. Takenaka T, Nagata H (2005) J Eur Ceram Soc 25:2693

11. Yi L, Moon K, Wong CP (2005) Science 308:1419

12. Shimamura K, Takeda H, Kohno T, Fakuda T (1996) J Cryst Growth 163:388

13. Hill NA, Rabe KM (1999) Phys Rev B 59:8759

14. Halasyamani PS, Poeppelmeier KR (1998) J Chem Mater 10:2753

15. Gordon JN, Taylor A, Bennette PN (2002) Br J Clin Pharmacol 53:451

16. Barltrop D, Smith AM (1985) Postgrad Med J 51:770

17. Rabinowitz MB, Wetherill GW, Kopple JD (1976) J Clin Invest $58: 260$

18. Courtney D, Meekin SR (1985) Occup Med 35:128

19. Control of Lead at Work Regulations (1998) London: The Stationery Office Ltd

20. Goering PL (1993) Neurotoxicology 14:45

21. Baldwin DR, Marshall WJ (1999) Ann Clin Biochem 36:267

22. Kety SS (1942) J Biol Chem 142:181

23. Leckie WJH, Tompsett SL (1958) Q J Med 27:65

24. Aposhian HV (1983) Ann Rev Pharmacol Toxicol 23:193

25. Graziano JH, Siris ES, Lolacono N, Silverberg SJ, Turgeon L (1985) Clin Pharmacol Ther 37:431

26. Takenaka T, Maruyama KI, Sakata K (1991) Jpn J Appl Phys Part 1(30):2236

27. Sasaki A, Chiba T, Mamiya Y, Otsuki E (1999) Jpn J Appl Phys Part 1(38):5564

28. Wang XX, Chan HLW, Choy CL (2005) App Phys A Mater Sci Process 80:333

29. Smolenskii GA, Isupov VA, Agranovskaya AI, Krainik NN (1961) Sov Phys Solid State 2:2651

30. Li YM, Chen W, Xu Q, Zhou J, Sun HJ, Xu R (2004) Mater Sci Eng B 112:5

31. Takenaka T, Maruyama K, Sakata K (1991) Jpn J Appl Phys 30(9B):2236

32. Shuvaeva VA, Zekria D, Glazer AM, Jiang Q, Weber SM, Bhattacharya P, Thomas PA (2005) Phys Rev B 71:174114

33. Wang XX, Tang XG, Kwok KW, Chan HLW, Choy CL (2005) Appl Phys A 80:1071

34. Zhao SC, Li GR, Ding AL, Wang TB, Yin QR (2006) J Phys D Appl Phys 39:2277

35. Xiao DQ, Lin DM, Zhu JG, Yu P (2006) J Electroceram 16:271

36. Peng CE (2006) Master's degree thesis, Tsinghua University, China, pp 66-75

37. Hiruma Y, Watanabe T, Nagata H (2008) Jpn J Appl Phys 47:7659

38. Takenaka T, Okuda T, Takegahara K (1997) Ferroelectrics 196:495

39. Nagata H, Koizumi N, Takenaka T (1999) Key Eng Mater 169170:37

40. Wang XX, Chan HLW, Choy CL (2003) J Am Ceram Soc $86: 1809$

41. Wang XX, Chan HLW, Choy CL (2003) Solid State Commun $125: 395$

42. Zhou CR, Liu XY (2008) J Mater Sci 43:1016. doi:10.1007/ s10853-007-2246-X

43. Mahboob S, Prasad G, Kumar GS (2007) J Mater Sci 42:10275. doi:10.1007/s10853-006-1122-4

44. Tian HY, Kwok KW, Chan HLW, Buckley CE (2007) J Mater Sci 42:9750. doi:10.1007/s10853-007-2005-Z

45. Herabut A, Safari A (1997) J Am Ceram Soc 80:2964
46. Li YM, Chen W, Xu Q, Zhou J, Sun HJ, Xu R, Liao MS (2005) J Electroceram 14:53

47. Takenaka T, Sakata K, Toda K (1990) Ferroelectrics 106:375

48. Wang X, Chan H, Choy C (2003) Sol Stat Comm 125:395

49. Li YM, Chen W, Xu Q, Zhou J, Gu X (2005) Mater Lett 59:1361

50. Chu BJ, Chen DR, Li GR, Yin QR (2002) J Eur Ceram Soc 22:2115

51. Wang TB, Gao M, Wang LE, Lu YK, Zhou DP (1987) J Inorg Mater 2:223

52. Li HD, Feng CD, Yao WL (2004) Mater Lett 58:1194

53. Nagata H, Takenaka T (1997) Jpn J Appl Phys 36(9B):6055

54. Nagata H, Takenaka T (1998) Jpn J Appl Phys 37(9B):5311

55. Zhou XY, Gu HS, Wang Y, Li WY, Zhou TS (2005) Mater Lett 59:1649

56. Ichinose N, Udagawa K (1995) Ferroelectrics 169:317

57. Kusumoto K, Ceramics Research Institute, National Institute of Advanced Industrial Science and Technology (AAST), Nagoya, Japan

58. Zhang YR, Li JF, Zhang BP (2008) J Am Ceram Soc 91:2716

59. Zhang YR, Li JF, Zhang BP, Peng CE (2008) J Appl Phys 103:074109

60. Yoo J, Oh D, Jeong Y, Hong J, Jung M (2004) Mater Lett 58:3831

61. Yoo J, Lee H, Lee B, Jeong Y, Hong J, Song H, Kwon J (2006) Sens Actuat A Phys 126:41

62. Peng C, Li J, Gong W (2005) Mater lett 59:1576

63. Lin DM, Xiao D, Zhu J, Yu P, Yan H, Li L (2004) Mater Lett 58:615

64. Lin DM, Xiao D, Zhu J, Yu P (2005) Phys Stat Sol 202:89

65. Lin DM, Xiao D, Zhu J, Yu P, Yan H, Li L, Zhang W (2004) Cryst Res Technol 39:30

66. Lam KH, Guo MS, Lin DM, Kwok KW, Chan HLW (2008) J Mater Sci 43:1677. doi:10.1007/s10853-007-2385-0

67. Nagata H, Yoshida M, Makiyuchi Y, Takenaka T (2003) Jpn J Appl Phys 42:7401

68. Li YM, Chen W, Xu Q, Zhou J, Sun H, Liao M (2005) Ceram Int 31:139

69. Li YM, Chen W, Xu Q, Zhou J, Gu X, Fang S (2005) Mater Chem Phys 94:328

70. Lam KH, Wang XX, Chan HLW (2006) Sens Actuat A 125:393

71. Jona F, Shirane G (1993) Ferroelectric crystals. Dover Publications Inc., New York, p 221

72. Egerton L, Dillom DM (1959) J Am Ceram Soc 42:438

73. Matsubara M, Kikuta K, Hirano S (2005) J App Phys 97:114

74. Seo IT, Cho KH, Park HY (2008) J Am Ceram Soc 91:3955

75. Park HY, Choi JY, Choi MK, Cho KH, Nahm S (2008) J Am Ceram Soc 91:2374

76. Bernard J, Bencan A, Rojac T, Holc J, Malic B, Kosec M (2008) J Am Ceram Soc 91:2409

77. Birol H, Damjanovic D, Setter N (2006) J Euro Ceram Soc 26:861

78. Li JF, Wang K, Zhang BP, Zhang LM (2006) J Am Ceram Soc $89: 706$

79. Zhang BP, Li JF, Wang K, Zhang H (2006) J Am Ceram Soc 89:1605

80. Saito Y, Takao H, Tani T, Nonoyama T, Takatori K, Homma T, Nagaya T, Nakamura M (2004) Nature 432:84

81. Kosec M, Kolar D (1975) Mater Res Bull 10:335

82. Ichiki M, Zhang L, Tanaka M, Maeda R (2004) J Eur Ceram Soc 24:1165

83. Gao DJ, Kwok KW, Lin DM, Chan HLW (2009) J Mater Sci 44:2466. doi:10.1007/s10853-009-3314-1

84. Bomlai P, Sukprasert S, Muensit S, Milne SJ (2008) J Mater Sci 43:6116. doi:10.1007/s10853-008-2940-3

85. Guo Y, Kakimoto K, Ohsato H (2005) Mater Lett 59:241 
86. Kim MS, Jeong SJ, Song JS (2007) J Am Ceram Soc 90:3338

87. Rubio-Marcos F, Ochoa P, Fernandez JF (2007) J Eur Ceram Soc 27:4125

88. Chang YF, Yang ZP, Hou YT, Liu ZH, Wang ZL (2007) Appl Phys Lett 90:232905

89. Lin DM, Kwok KW, Chan HLW (2007) J Appl Phys 102:034102

90. Dai Y, Zhang X, Zhou G (2007) Appl Phys Lett 90:262903

91. Matsubara M, Yamaguchi T, Sakamoto W, Kikuta K, Yogo T, Hirano S (2005) J Am Ceram Soc 88:1190

92. Saito Y, Takao H (2006) Ferroelectrics 338:17

93. Yang Z, Chang Y, Liu B, Wei L (2006) Mater Sci Eng A 432:292

94. Wu JG, Peng T, Wang YY, Xiao DQ, Zhu JM, Jin Y, Zhu JG, Yu P, Wu L, Jiang YH (2008) J Am Ceram Soc 91:319

95. Zhang SJ, Xia R, Shrout TR, Zang GZ, Wang JF (2006) J Appl Phys 100:104108

96. Wu JG, Xiao DQ, Wang YY, Zhu JG, Wu L, Jiang YH (2007) Appl Phys Lett 91:252907

97. Du HL, Liu DJ, Tang FS, Zhu DM, Zhou WC (2007) J Am Ceram Soc 90:2824

98. Du HL, Luo F, Qu SB, Pei ZB, Zhu DM, Zhou WC (2007) J Appl Phys 102:054102

99. Wu JG, Wang YY, Xiao DQ, Zhu JG, Pu ZH (2007) Appl Phys Lett 91:132914

100. Wang YY, Wu JG, Xiao DQ, Zhu JM, Jin Y, Zhu JG, Yu P, Wu L, Li X (2007) J Appl Phys 102:054101

101. Wu JG, Wang YY, Xiao DQ, Zhu JG (2007) Phys Status Solidi Rapid Res Lett 1:214

102. Malic B, Bernard J, Bencan A, Kosec M (2007) J Eur Ceram Soc 28:1191

103. Guo Y, Kakimoto K, Ohsato H (2004) Appl Phys Lett 85:4121

104. Li HD, Shih WY, Shih WH (2007) J Am Ceram Soc 90:3070

105. Park SJ, Park HY, Cho KH (2008) Mater Res Bull 43:3580

106. Zhao P, Zhang BP (2008) J Am Ceram Soc 91:3824

107. Zhao P, Tu R, Goto T (2008) J Am Ceram Soc 91:3440

108. Wu JG, Xiao DQ, Wang YY (2008) J Am Ceram Soc 91:3402

109. Wang Y, Wu J, Xiao D, Wu W, Zhang B, Wu L, Zhu J (2008) J Am Ceram Soc 91:2772

110. Malic B, Bernard J, Holc J, Jenko D, Kosec M (2005) J Eur Ceram Soc 25:2707
111. Guo Y, Kakimoto K, Ohsato H (2004) Solid State Commun 129:279

112. Kosec M, Malic B, Bernard J, Holc J, Hrovat M, Bobnar V (2004) J Mater Res 19:1849

113. Chang YF, Yang ZP, Chao XL, Zhang R, Li XR (2007) Mater Lett 61:785

114. Chang Y, Yang Z, Wei L, Liu B (2006) Mater Sci Eng A 437:301

115. Zhao S, Zhang L, Li G, Wang T, Ding A (2005) Phys Stat Sol 202:R22

116. Lu YT, Chen XM, Jin DZ, Hu X (2005) Mater Res Bull 40:1847

117. Yan H, Zhang H, Ubic R, Reece MJ, Liu J, Shen Z, Zhang Z (2005) J Adv Mater 17:1261

118. Cross LE, Pohanka RC (1971) Mater Res Bull 6:939

119. Gao X, Zhou Z, Xue J, Wang J (2005) J Am Ceram Soc 88:1037

120. Huseyin Y, Susan T, Gary M (2003) J Electro Ceram 11:217

121. Matsuo K, Xie RJ, Akimune Y, Sugiyama T (2002) J Ceram Soc Jpn 110:491

122. Martin PD, Castro A, Millan P, Enez BJ (1998) J Mater Res 13:2565

123. Patro PK, Kulkarni AR, Gupta SM, Harendranath CS (2006) In: Kharat DK (ed) National seminar on advances in electroceramics (NSAE-2006), Armament Research \& Development Establishment, Pune, India, pp 146-153

124. Moulson AJ, Herbert JM (1992) Electroceramics: materials, properties, applications. Chapman and Hall, London

125. Xie RJ, Akimune Y (2002) J Mater Chem 12:3156. doi:10.1039/ b202923p

126. Measurement of properties of piezoelectric ceramics, Sensor Technology Limited (1991) Manufacturer Handbook, BM91309

127. Zhou QF, Chan HLW, Choy CL (1997) J Mater Process Tech 63:281

128. Ounaies Z (1995) Sol-gel and microwave processing of PZT materials for sensor and actuator application. The Pennsylvania State University, PA, USA

129. Levinson LM (1998) Electronic ceramics: properties, devices and applications. General Electric Company, New York 